\title{
Universiteit
}

Leiden

The Netherlands

\section{Biorefining of lignocellulosic feedstock: technical, economic and environmental considerations}

Luo, L.; Voet, E. van der; Huppes, G.

\section{Citation}

Luo, L., Voet, E. van der, \& Huppes, G. (2010). Biorefining of lignocellulosic feedstock: technical, economic and environmental considerations. Bioresource Technology, 101(13), 5023-5032. doi:10.1016/j.biortech.2009.12.109

Version: Publisher's Version

License: $\quad$ Licensed under Article 25fa Copyright Act/Law (Amendment Taverne)

Downloaded from: https://hdl.handle.net/1887/3193704

Note: To cite this publication please use the final published version (if applicable). 


\title{
Biorefining of lignocellulosic feedstock - Technical, economic and environmental considerations
}

\author{
Lin Luo*, Ester van der Voet, Gjalt Huppes \\ Institute of Environmental Sciences (CML), Leiden University, P.O. Box 9518, 2300 RA Leiden, The Netherlands
}

\section{A R T I C L E I N F O}

\section{Article history:}

Received 17 September 2009

Received in revised form 23 December 2009

Accepted 24 December 2009

Available online 21 January 2010

\section{Keywords:}

Biorefinery

Corn stover

Eco-efficiency

Internal rate of return

Net present value

\begin{abstract}
A B S T R A C T
Biorefinery, an example of a multiple products system, integrates biomass conversion processes and equipment to produce fuels, power and chemicals from biomass. This study focuses on technical design, economic and environmental analysis of a lignocellulosic feedstock (LCF) biorefinery producing ethanol, succinic acid, acetic acid and electricity. As the potential worldwide demand of succinic acid and its derivatives can reach 30 million tons per year, succinic acid is a promising high-value product if production cost and market price are substantially lowered. The results of the economic analysis show that the designed refinery has great potentials compared to the single-output ethanol plant; even when the price of succinic acid is lowered or the capital investment doubled. In terms of eco-efficiency, the LCF biorefinery shows better environmental performances mainly in global warming potential due to $\mathrm{CO}_{2}$ fixation during acid fermentation. The overall evaluation of the eco-efficiency depends on the importance attached to each impact category.
\end{abstract}

(c) 2009 Elsevier Ltd. All rights reserved.

\section{Introduction}

Crude oil refinery started with distillation and ended up combining it with sophisticated reaction engineering to develop complex material and energy networks making use of every ounce from a barrel of oil. Facing the threat of oil depletion and climate change, a shift to renewable resources is being made to ensure long-term supplies. A biorefinery is a facility that integrates biomass conversion processes and equipment to produce fuels, power, and chemicals from biomass (NREL, 2009). It stands ready for the transformation with recovery of sugars being combined with a variety of new fermentation and thermo-chemical processes. Careful management and utilization of materials, products and wastes are desirable, making biorefinery a clear example of industrial symbiosis - resource sharing and by-product (waste) exchange among nearby industries within the network. This type of network activity seems often to have both environmental and economic benefits, and it may include mechanisms for making industry more sustainable (Realff and Abbas, 2004). By producing multiple products and integrating waste treatment, biorefineries can maximize the values derived from biomass feedstocks and turn biomass processing into real opportunities.

Three types of biorefineries known as phase I, II and III have been described by Kamm and Kamm (2004) and van Dyne et al. (1999). The phase I and II biorefinery plants use grain as feedstocks

\footnotetext{
* Corresponding author. Tel.: +31 71 5271497; fax: +31 715277434

E-mail address: luo@cml.leidenuniv.nl (L. Luo).
}

such as corn and wheat. The difference is that phase I biorefinery has fixed processing capabilities and produces a fixed amount of ethanol and other feed products, while phase II biorefinery has the capability to produce various end products and has far more processing flexibility. Typical examples for phase I and II biorefinery are corn dry milling and corn wet milling, respectively. The latter one uses corn as the feedstock and produces multi-products such as gluten feed, high fructose corn syrup (HFCS), starch, glucose and dextrose, ethanol, gluten meal, and corn oil. A phase III refinery, the most promising to be developed, uses a mix of biomass feedstocks and yields an array of products by employing combination of technologies (Kamm and Kamm, 2004). It allows a mix of agriculture feedstocks, has the ability to use various types of processing methods, and has the capability to co-produce a mix of high-value chemicals in low volume while producing a bulk product like ethanol in high volume.

The phase III biorefineries combine whole-crop, green and lignocellulosic feedstock (LCF) biorefineries. A whole-crop biorefinery consumes and processes the entire crop to obtain useful products. A green biorefinery is a multi-product system which handles natural wet feedstocks derived from untreated products such as grass, green plants or green crops as inputs. In an LCF biorefinery, cellulosic biomass or wastes is initially cleaned and degraded into three fractions (cellulose, hemicellulose and lignin) via chemical digestion or enzymatic hydrolysis. The cellulose and hemicellulose are further processed to produce useful products such as fuels and chemicals, and the lignin has only limited uses, such as a fuel for direct combustion to generate steam and electricity. 
The development and perspectives of LCF biorefineries have been extensively discussed in the literature studies. Kadam et al. presented a biorefinery converting corn stover into fuel ethanol, dissolving pulp and lignin for resin production (Kadam et al., 2008); Kaparaju et al. (2009) established a biorefinery framework producing bioethanol, bio-hydrogen and biogas from wheat straw; Laser et al. (2009a,b) also proposed several scenarios in which fuels, power and animal feed protein are produced in one biorefinery. All these studies indicate that multiple products biorefineries are the future of biomass refining. Nevertheless, none has focused on a detailed technical design combining with economic and environmental analysis of a refinery converting LCF to fuel, power and high-value chemicals.

The present study involves designing a LCF biorefinery producing ethanol, succinic acid, acetic acid and electricity from corn stover, and next analyzing the refinery from an economic and environmental point of view. This study aims at optimizing the biorefinery in terms of technology, energy efficiency and environmental impact; bridging technical process design to system analysis; and providing indications on the sustainability of such a refinery.

\section{Methods}

\subsection{Description of the design}

The focus of this study is the technical design and system analysis of a phase III biorefinery - LCF biorefinery. In this section product selection and process design are discussed.

\subsubsection{Product selection criteria}

For product selection a portfolio of candidates needs to be developed. A set of criteria was defined to select products to be included in the portfolio. Candidates were evaluated against the following criteria to decide their inclusion in the portfolio (Landucci et al., 1994):

- High theoretical product yield from substrate.

- Market interest in the product as an end product or important intermediate.

- High product volume (current or potential).

- Non-food use.

- Ability to be biologically synthesized from the common sugars derived from various forms of biomass.

\subsubsection{Selection of products}

The primary product in this study is chosen to be second generation ethanol, which is produced in large volume in the refinery. The reason for the choice now is the strong promotion of bioethanol as a transport fuel in both Europe and US. Ethanol produced from a bioprocess instead of a traditional chemical process fulfils all the aforementioned criteria, and currently is the most competitive fuel option compared to gasoline.

Based on the similar selection criteria mentioned above, Landucci et al. (1994) made a product portfolio which consists of 40 products. Fourteen of the 40 were classified as near-term opportunity, which are alginate, citric acid, fumaric acid, gluconic acid, itaconic acid, lactic acid, lysine, malic acid, protease, pullulan, rhamsan gum, scleroglucan, succinic acid and xanthan gum. Succinic acid is selected here to be the main chemical produced from the refinery due to its FRF (Fraction of Revenue for Feedstock) value and judgment from a number of industrial experts.

Succinic acid is a common intermediate in the metabolic pathway of several anaerobic and facultative microorganisms. All the succinic acid producing bacteria from mixed-acid fermentations produce varying amounts of succinate as well as other products, including ethanol, lactic acid, acetic acid and formic acid. For instance, Escherichia coli produces succinate as a minor fermentation product, typically $0.12 \mathrm{~mol} / \mathrm{mol}$ glucose (Wood, 1961). On the other hand, Anaerobiospirillum succiniciproducens forms succinate up to $1.2 \mathrm{~mol} / \mathrm{mol}$ glucose (Samuelov et al., 1991; Nghiem et al., 1997). A recent study on a Corynebacterium glutamicum strain ( $\Delta l d h A-p C R A 717)$ shows that succinic acid is efficiently produced at high-cell density under oxygen deprivation with intermittent addition of sodium bicarbonate and glucose. The yields of succinic acid and acetic acid from glucose are reported to be $1.4 \mathrm{~mol} / \mathrm{mol}$ and $0.29 \mathrm{~mol} / \mathrm{mol}$, respectively (Okino et al., 2008).

In the biorefinery designed in this study, ethanol is produced as a main bulk fuel; succinic acid is the main chemical; acetic acid is produced simultaneously from mixed-acid fermentation as byproduct; steam and electricity are generated from process wastes. An important reason for combining ethanol with succinic acid production is that the $\mathrm{CO}_{2}$ emerging from ethanol fermentation can be utilized in the acid fermentation, without emission. This is of crucial importance from an environmental point of view.

\subsubsection{Design of the biorefinery}

After the products are selected, the issues concerning the design of the biorefinery are presented in this section. For technical design and mass balance we used SuperPro Designer ${ }^{\circledR}$ from Intelligen Inc.

\section{(1) Feedstock availability}

Biomass availability is a critical issue. Global bio-based production should be based on decreasing competition with food and land use, thus low-value agricultural co-products and wastes are more favourable than conventional products like corn. Corn stover, the crop residue in the corn field, is produced at a rate of $1 \mathrm{dry} \mathrm{kg}$ per dry kg of corn grain. To avoid conflicts between food/feed uses and industrial uses of crops, US Department of Energy (DOE) is interested in utilizing part of the stover for ethanol production, competing with fodder only. Proponents of stover use claim that as much as $60 \%$ of the gross stover produced each year can be collected and converted to fuel ethanol (Sheehan et al., 2002) while maintaining soil productivity. Under this practice, $312 \mathrm{Tg}$ of dry corn stover are globally available for further processing. The technology to produce ethanol from stover has already been studied by NREL (Aden et al., 2002). Lignin-rich fermentation residues are generated during corn stover-based processing to bioethanol (McAloon et al., 2000). These residues can be used for steam and electricity cogeneration. In this study corn stover is selected as the feedstock. Other cellulosic feedstocks such as straw, sugarcane bagasse, switchgrass, and woodchip can also be utilized, but research on specific processing technologies is required.

\section{(2) Location and scale}

The LCF biorefinery is assumed to be located in the middle of the Corn Belt farmland, State of Iowa, mid-west of the United States, to minimize transport distances. The stover is collected within an $80 \mathrm{~km}$ (50 miles) radius around the refinery (Aden et al., 2002). The harvested stover is transported by lorries. The capacity of the refinery and the prices of the feedstock and products are given in Table $1 \mathrm{a}$.

\section{(3) Process overview and design}

The refinery is designed to operate $24 \mathrm{~h}$ per day, and 335 days (11 months) per year continuously. The remaining 1 month is used for cleaning-up and restarting the operations. As crop residues are harvested and transported at different time of the year, long-term 
Table 1

Production capacity and prices of feedstock and products (a) biorefinery in this study (b) ethanol plant by Aden et al. (2002).

\begin{tabular}{|c|c|c|c|c|}
\hline Component & Amount & Price & Proceeds (million \$/year) & Reference \\
\hline \multicolumn{5}{|l|}{ (a) } \\
\hline Corn stover & $1,581,203$ tons/year & $0.033 \$ / \mathrm{kg}$ & 52.18 & Graham et al. (2007) \\
\hline Ethanol & 170,729 tons/year & $0.357 \$ / \mathrm{kg}$ & 60.95 & Lynd et al. (2005) \\
\hline Succinic acid & 294,819 tons/year & $1.000 \$ / \mathrm{kg}^{\mathrm{a}}$ & 294.82 & This study \\
\hline Acetic acid & 12,615 tons/year & $0.700 \$ / \mathrm{kg}$ & 8.83 & ISIC Pricing (2009) \\
\hline Electricity & $122,469,863$ kW h/year & $0.110 \$ / \mathrm{kW} \mathrm{h}$ & $13.47^{\mathrm{b}}$ & Saving Electricity (2009) \\
\hline \multicolumn{5}{|l|}{ (b) } \\
\hline Corn stover & 821,183 tons/year & $0.033 \$ / \mathrm{kg}$ & 27.10 & Graham et al. (2007) \\
\hline Ethanol & 206,770 tons/year & $0.357 \$ / \mathrm{kg}$ & 73.82 & Lynd et al. (2005) \\
\hline
\end{tabular}

$\$ / \mathrm{kg}$ is given in Section 3.1 .

a The current market price is $5.90 \$ / \mathrm{kg}$ (Lynd et al., 2005), the description of the assumption of 1.0.

b In case of the use of co-produced electricity in the plant itself, this represents avoided costs.

storage is required to provide feedstocks to the plant year-round. The life time of the refinery is assumed to be 20 years. The process overview is shown in Fig. 1.

2.1.3.1. Feedstock handling and pre-treatment. The aim of feedstock handling is feedstock washing and size reduction. Different pretreatment methods including physical, chemical, thermo-chemical and biological treatment have been reviewed by Sun and Cheng (2002). Dilute acid pre-hydrolysis is selected for the pre-treatment of corn stover following the choice of Aden et al. (2002). The pretreatment step, in which dilute sulphuric acid and high temperature $\left(190^{\circ} \mathrm{C}\right)$ are engaged, converts most of the hemicellulose portion to soluble sugars - primarily xylose, arabinose, mannose and galactose. Glucan in the hemicellulose and a small portion of the cellulose are converted to glucose. The main reactions and the Fractions Converted to Product (FCP) in the pre-hydrolysis are given in Eqs. (1)-(5). The other hemicellulose carbohydrates (arabinan, mannan, and galactan) are assumed to have the same reactions and conversions as xylan

Glucan: $\quad(\text { Glucan })_{n}+n \mathrm{H}_{2} \mathrm{O} \rightarrow n$ Glucose $\mathrm{FCP}: 0.07$

Xylan: $\quad(\text { Xylan })_{n}+n \mathrm{H}_{2} \mathrm{O} \rightarrow n$ Xylose $\mathrm{FCP}: 0.90$

Xylan : $\quad(\text { Xylan })_{n} \rightarrow n$ Furfural $+2 n \mathrm{H}_{2} \mathrm{O} \quad$ FCP : 0.05

Acetate : Acetate $\rightarrow$ Acetic acid FCP : 1.00

Lignin : $\quad(\text { Lignin })_{n} \rightarrow n$ Soluble lignin $\quad$ FCP : 0.05

2.1.3.2. Bioconversion. Following the pre-treatment, a liquid-solids separation removes cellulose (solids) from the soluble sugars, which are then sent to fermentation for ethanol production. The cellulose is sent to saccharification, where cellulase enzyme is used to obtain mainly glucose. Cellulase enzyme is a collection of enzymes, which is comprised of endoglucanases for polymer size reduction, exoglucanases for crystalline cellulose hydrolysis, and $\beta$-glucosidase for cellobiose hydrolysis to glucose. The most common organism used to produce cellulase industrially is Trichoderma reesei. The reaction and FCP in the enzyme hydrolysis are shown in Eq. (6)

Glucan: $\quad(\text { Glucan })_{n}+n \mathrm{H}_{2} \mathrm{O} \rightarrow n$ Glucose $\mathrm{FCP}: 0.90$

The glucose after enzyme hydrolysis is converted to succinic acid (main product) and acetic acid (co-product) by fermentation. The reason for this choice is that genetically modified strains have been developed to ferment both hexose and pentose sugars to ethanol; however, succinic acid production is still limited in using natural strains as biocatalysts, most of which can only utilize glucose. Depending on the market demand of succinic acid, the ratio of cellulose for the production of ethanol versus succinic acid can be determined.
There are various recombinant microorganisms that can utilize both pentose and hexose sugars. The main disadvantages of these organisms are their low productivities and stabilities. Recombinant Zymomonas mobilis is a promising bacterium for future ethanol production (Zhang et al., 1995), and it has been selected in this study for fermentation of pentose to ethanol. It is assumed that all the major pentose sugars (xylose and arabinose) are fermented together. The reactions and FCPs are given in Eqs. (7)-(17)

Glucose : Glucose $\rightarrow 2$ Ethanol $+2 \mathrm{CO}_{2} \quad \mathrm{FCP}: 0.950$

Glucose: Glucose $+2 \mathrm{H}_{2} \mathrm{O} \rightarrow 2$ Glycerol $+\mathrm{O}_{2}$ FCP : 0.004

Glucose: Glucose $+2 \mathrm{CO}_{2} \rightarrow 2$ Succinic acid $+\mathrm{O}_{2}$ FCP : 0.006

Glucose : Glucose $\rightarrow 3$ Acetic acid FCP : 0.015

Glucose : Glucose $\rightarrow 2$ Lactic acid FCP : 0.002

Xylose : 3 Xylose $\rightarrow 5$ Ethanol $+5 \mathrm{CO}_{2} \quad \mathrm{FCP}: 0.850$

Xylose : 3 Xylose $+5 \mathrm{H}_{2} \mathrm{O} \rightarrow 5$ Glycerol $+2.5 \mathrm{O}_{2} \quad \mathrm{FCP}: 0.003$

Xylose: Xylose $+\mathrm{H}_{2} \mathrm{O} \rightarrow$ Xylitol $+0.5 \mathrm{O}_{2} \quad \mathrm{FCP}: 0.046$

Xylose : 3 Xylose $+5 \mathrm{CO}_{2} \rightarrow 5$ Succinic acid $+2.5 \mathrm{O}_{2}$ FCP : 0.009

Xylose : 2 Xylose $\rightarrow 5$ Acetic acid FCP : 0.014

Xylose : 3 Xylose $\rightarrow 5$ Lactic acid FCP : 0.002

For the fermentation of glucose to succinic acid and acetic acid, recombinant $C$. glutamicum is chosen as the biocatalyst because it forms succinic acid in a high concentration of about $146 \mathrm{~g} / \mathrm{l}$ under anaerobic conditions in the presence of carbon dioxide (Okino et al., 2008). The reactions and FCPs are given in Eqs. (18) and (19)

Glucose : Glucose $+2 \mathrm{CO}_{2} \rightarrow 2$ Succinic acid $+\mathrm{O}_{2} \quad$ FCP : 0.70

Glucose : Glucose $+\rightarrow 3$ Acetic acid FCP : 0.10

2.1.3.3. Downstream processing. For the ethanol recovery, distillation and molecular sieve adsorption are used to produce $99.9 \%$ ethanol. Distillation is accomplished in two columns - the first, called the beer column, removes the dissolved $\mathrm{CO}_{2}$ and most of the water, and the second concentrates the ethanol to a new azeotropic composition. All the water from the nearly azeotropic mixture is removed by vapour phase molecular sieve adsorption. The fermentation vent (containing mostly $\mathrm{CO}_{2}$, but also some ethanol) and the beer column are scrubbed in a water scrubber, recovering nearly all of the ethanol. The vent from the scrubber (mostly $\left.\mathrm{CO}_{2}\right)$ is compressed and sent to the fermenter for succinic acid production. 


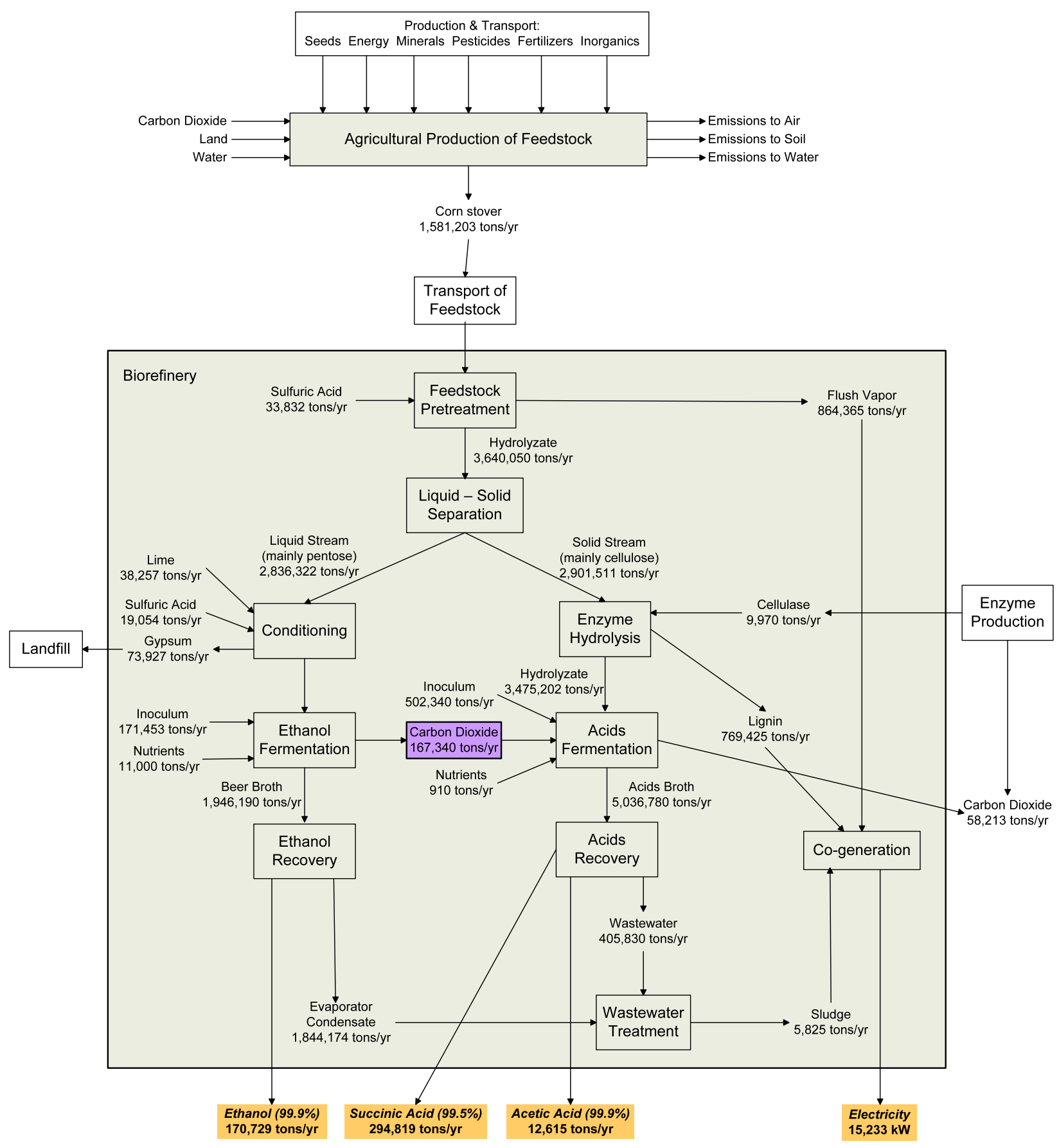

Fig. 1. Process flow scheme of the LCF biorefinery.

An emerging technology, which holds higher potential for commercialization and environmentally friendly processes for succinic acid purification, is simultaneous acidification by ion-exchange resins and a crystallization process (Zeikus, 1995). This technology is selected due to its cost-effectiveness and ease of scaling up to commercial use. Nevertheless, the major limitation of this process is that the membranes cannot handle divalent cations; therefore, the fermentation is neutralized with sodium hydroxide, forming soluble sodium succinate during the fermentation. The whole broth is filtered with a microfilteration unit to separate the cells and large insoluble particles from the succinate broth. The filtered sodium succinate is fed to a batch desalting electrodialysis unit, where the ionic species are separated from the non-ionic ones (sugars) and molecules with large molecular masses. The sodium succinate solution is then fed to a batch bipolar membrane electro- dialysis unit where the ionic species are converted to their equivalent acid and base forms and separated. Sodium ions are transported across the cation membrane and associate with the hydroxyl ions to form sodium hydroxide, which is reused for fermenter neutralization. After succinic acid is purified (99.5\%), a further distillation is engaged to purify acetic acid to $99.9 \%$.

Part of the evaporator condensate, along with other wastewater from the plant is treated by anaerobic and aerobic digestion in the wastewater treatment section. The biogas (high methane concentration) from anaerobic digestion is sent to the combustor for energy recovery. The treated water is suitable for recycling and is returned to the process to use.

The solids containing lignin from the distillation, the concentrated syrups from the two production recovery systems, the biogas and the sludge from the wastewater treatment are com- 
busted in a fluidized bed combustor to produce high-pressure steam for electricity generation and process heat. Generally, the process produces excess steam that is converted to electricity for use in the plant and for sale to the grid.

\section{(4) Logistics}

As mentioned previously, corn stover is transported by lorries. On-site short-term storage is provided equivalent to $72 \mathrm{~h}$ of production at an outside storage area. The stored material provides a short-term supply for weekends, holidays, and when normal direct delivery of material into the process is interrupted. The material will be rotated continuously, with a first-in, first-out inventory management strategy.

Except corn stover, other chemicals needed for the production are purchased from the closest production sites in order to shorten the transport distance. Only if the prices are comparatively high, longer distance transportation will be considered. In this study, we assume the electricity generated in the refinery is one co-product; while the electricity required is purchased from the grid. An alternative is, assuming that the produced electricity is used in the process and either the excess is sold to the grid, or the additionally required electricity is bought from the grid. Product and feed chemical storage section includes the storage of ethanol, succinic acid, acetic acid, chemicals needed for the plant, cellulose enzyme, and water for fire suppression.

The stored ethanol is transported to the nearby refinery to be blended into gasoline to produce biofuels. The acetic acid can be sold to the chemical industries. The succinic acid can be sold directly, or a flexible production section can be established in the biorefinery to produce other products from succinic acid according to the market demand. Whenever changes in the market occur, the production line can be switched easily from one to another.

\subsubsection{Market analysis}

As succinic acid is the main high-value chemical produced from the refinery with large quantity, market analysis of succinic acid is of crucial importance. Today, succinic acid is mainly produced by chemical process from $n$-butane/butadiene via maleic anhydride (Bechthold et al., 2008). There are four major existing markets for succinic acid: (1) as a surfactant/detergent; (2) as an ion chelator, where it is used in electroplating to prevent corrosion and pitting of metals; (3) food market, where it is used as an acidulent/pH modifier, as a flavouring agent, and as an anti-microbial agent; (4) the production of health-related agents, including pharmaceuticals, antibiotics, amino acid and vitamins (Zeikus et al., 1999). The current world market for succinic acid is negligibly small. At present about 25,000 tons of succinic are produced worldwide; the market is growing by about $10 \%$ per year (BIOPRO, 2009). This is particularly due to the high conversion cost of maleic anhydride to succinic acid by the chemical process, which keeps the price high and limits the use of succinic acid for a wider range of applications.

However, beyond fossil-based chemistry, succinic acid can be used as a precursor of many industrially important chemicals including adipic acid, 1,4-butanediol, tetrahydrofuran, $\mathrm{N}$-methyl pyrrolidinone, 2-pyrrolidinone, succinate salts and gamma-butyrolactone (Song and Lee, 2006). Furthermore, the increasing demand for succinic acid is expected and its use is extended to the synthesis of biodegradable polymers such as polybutyrate succinate (PBS) and polyamides (Nylon ${ }^{\circledR} \mathrm{x}, 4$ ) (Willke and Vorlop, 2004) and various green solvents (Rudner et al., 2005). The market demand of several derivatives of succinic acid has been studied. The chemical industry produces about 900,000 tons petro-based 1,4-butanediol per year (BIOPRO, 2009); more than 230,000 tons of gamma-butyrolactone are produced worldwide (McKinlay et al., 2007); the esti- mated potential market size for the polymers polysuccinate esters and polyamides that can be synthesized from succinic acid is up to 27 million tons per year in 2001 (Baum and Engelmann, 2001). Therefore, the worldwide demand of succinic acid and its derivatives can reach 30 million tons per year, and probably will keep growing. The succinic acid produced from the refinery designed in this study is about 295,000 tons per year, which only accounts for about $1 \%$ of the potential worldwide demand. This suggests that the designed biorefinery has a reasonable scale in terms of the quantity of its outputs.

\subsection{System analysis}

The system analysis in this study focuses on environmental and economic aspects. Social aspects are left out of research. In this section an economic analysis and eco-efficiency estimation are presented.

\subsubsection{Economic analysis}

First of all, bio-based products must be made at competitive costs, which means, the biorefinery has to be profitable. Otherwise, there will be no market for the products even though they are made form renewable resources.

In this study an economic analysis has been conducted to estimate the net present value (NPV) and internal rate of return (IRR), which is based on the capital investment, and on the variable and fixed operating costs of the refinery. The discount rate for this analysis was set at $10 \%$, which was selected based on the recommendation by Short et al. (1995). The construction period of the refinery is assumed to be 3 years. The first year expense is the engineering, construction and contingency costs. In the second year $80 \%$ of the total capital investment is assumed to be made and the investment is finished in the third year. It is assumed that the refinery starts to be operated at $75 \%$ capacity in the third year, and at full capacity (11 months per year) in the rest of the life time.

The current market price of succinic acid is found to be $\$ 5.90 / \mathrm{kg}$ (Lynd et al., 2005). This high price is particularly due to the high conversion cost of maleic anhydride to succinic acid by the chemical process route. When adding substantially higher amounts of products to the market, the market price will collapse to a level where other applications can take up the large volumes. As succinic acid can be the precursor of several commodity chemicals which are produced in large quantity by chemical processes, the market price of succinic acid is expected to be drastically lowered to the level where it can take over the market. The price of 1,4butanediol is $\$ 2.76 / \mathrm{kg}$ in 2004 (McKinlay et al., 2007), and it can be produced from succinate in a two-step process (Paster et al., 2003). In order to assess whether the refinery would be competitive in a substantially extended market, we calculate with a price of $\$ 1.00 / \mathrm{kg}$, the price of succinic acid is substantially lower than the present price of 1,4-butanediol. In addition, we perform a sensitivity analysis for the price of succinic acid to assess its impact on the economic viability of the operation.

The results of the economic analysis were compared with the ones from the ethanol plant designed by Aden et al. (2002) from NREL. The production capacity of the ethanol plant and the prices of the feedstock and product are given in Table $1 \mathrm{~b}$. As our refinery aims at producing larger amount of high-value products (succinic acid), the market price of succinic acid will strongly affect the economic viability of the refinery. Moreover, the production costs of the refinery may have been underestimated, as novel designs tend to come out more expensive than originally planned. Hence, sensitivity analyses were conducted on the capital investment, the market price of both succinic acid and ethanol, and the purchase price of the feedstock corn stover Table $1 \mathrm{~b}$. 
Table 2

Cost breakdown of the biorefinery.

\begin{tabular}{|c|c|c|c|}
\hline Item & Description & Amount & Unit \\
\hline Capital investment & & 388.75 & million \$ \\
\hline Total installed cost & Cost of installed equipment, warehouse and site development & 238.79 & million $\$$ \\
\hline Prorateable costs & $10 \%$ of total installed cost & 23.88 & million \$ \\
\hline Field expenses & $10 \%$ of total installed cost & 23.88 & million \$ \\
\hline Home office and construction fee & $25 \%$ of total installed cost & 59.70 & million $\$$ \\
\hline Project contingency & $3 \%$ of total installed cost & 7.16 & million \$ \\
\hline Other costs & $10 \%$ of the aforementioned costs & 35.34 & million $\$$ \\
\hline Variable operating costs & & 111.20 & million \$/year \\
\hline Materials and chemicals & Feedstock and process chemicals & 65.75 & million \$/year \\
\hline Energy costs ${ }^{*}$ & Mainly electricity $(47,591 \mathrm{~kW})$ & 42.09 & million \$/year \\
\hline Waste handling charges & & 3.36 & million \$/year \\
\hline Fixed operating costs & & 14.78 & million \$/year \\
\hline Total salaries & & 4.30 & million \$/year \\
\hline General overhead & $60 \%$ of total salaries & 2.58 & million \$/year \\
\hline Maintenance & $2 \%$ of installed equipment cost & 4.32 & million \$/year \\
\hline Insurance and taxes & $1.5 \%$ of total installed cost & 3.58 & million \$/year \\
\hline
\end{tabular}

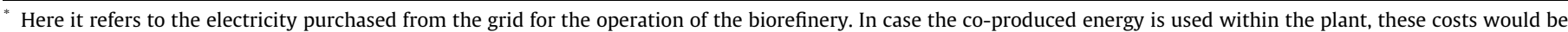
$\$ 13$ million/year lower, and the proceeds would also be reduced with the same amount.

\subsubsection{Environmental impact assessment}

For the environmental performance of the refinery the full production system is assed, "cradle-to-gate". The following impact categories are taken into account, and the software package (CMLCA, 2009) is used for environmental analysis. This environmental impact assessment is performed to obtain a first idea of the benefits of biorefineries in that area.

- Abiotic depletion potential (ADP).

- Global warming potential (GWP).

- Ozone layer depletion potential (ODP).

- Photochemical oxidation potential (POCP).

- Human toxicity potential (HTP).

- Eco-toxicity potential (ETP).

- Acidification potential (AP).

- Eutrophication potential (EP).

- Comparison of eco-efficiency.

In this study eco-efficiency is defined as 'emissions per unit of output', as in line with the definition made by the World Business Council (Schmidheiny, 1992). This represents the environmental intensity of production, thus the lower the eco-efficiency number the better the performance. The total output is defined as the total of all values (summation of the market prices of all the products, expressed in dollar) derived from the refinery. As we account for the total production from the refinery, no allocation of emissions is needed among products. However, for the "cradle" of the analysis, agricultural production, all inputs and emissions need to be allocated between corn and stover, and in this case economic allocation is applied, as is usual in managerial cost allocation as well.

A research question is raised as 'How are the economic feasibility and environmental performance compared to a single product ethanol production plant?' In order to project the environmental potential of such a refinery system, the results of eco-efficiency of the biorefinery were compared with the ones from the ethanol plant designed by Aden et al. (2002) from NREL. In the ethanol plant corn stover is converted to ethanol using advanced cellulosic technology, and the steam and electricity required is generated from lignin and wastes. There is no co-product or surplus of electricity; hence ethanol is the only product. In both the biorefinery designed in this study and the ethanol plant designed in NREL advanced technologies have been used and the processes have been optimized. As the capacity of the biorefinery in terms of feedstock handling is twice as high as for the ethanol plant, the capital investment and operating cost of the biorefinery are much higher resulting in incomparable NPV. Nevertheless, the values of IRR from both systems are well comparable.

As blends of ethanol and gasoline with different percentage are already used in practice as transport fuels, it is important to also compare the eco-efficiency of biorefinery and ethanol plant with the gasoline refinery. The current market price of gasoline is around $\$ 2.70 /$ gallon including excises (EIA, 2009). In this comparative study the use phases of all the products are not taken into account.

\section{Results}

In this section the results of the system analysis are presented including economic analysis and its sensitivity analyses, environmental impact assessment, and the comparison of eco-efficiency of gasoline refinery, ethanol plant and biorefinery designed in this study.

\subsection{Economic analysis}

The basis for determining the breakdown of the production costs of the biorefinery is the method used by Aden et al. (2002). The description and the results including fixed capital investment, variable and fixed operating costs are given in Table 2.

The results of NPV and IRR in comparison with the ones from the ethanol production plant are given in Table 3.

The capital investment, variable and fixed operating costs of the ethanol plant were estimated in the NREL report (Aden et al., 2002). The internal rate of return (IRR) is the value of the discount rate for which the net present value is null. Generally speaking, the higher the IRR of the project, the more desirable it is to be undertaken. In the study by Aden et al. (2002), IRR is estimated to be $13 \%$. In another study the IRR of an ethanol plant is reported as $20-30 \%$ (Efe et al., 2005), but assumptions may have been made differently, which is the reason why it is not used as a reference for comparison in our study. It can be seen that the biorefinery is economically much more viable than the ethanol plant as its high IRR (46\%) shows. This is mainly due to the cost reduction of combined installations and the market price of high-value chemicals.

The results of sensitivity analysis on the capital investment, the market price of succinic acid and ethanol, and the purchase price of corn stover are given in Table 4.

It can be seen that when the capital investment becomes twice as high as the current value, the refinery can still profit (IRR 26\%) 
Table 3

Comparative results of biorefinery and ethanol plant from economic analysis.

\begin{tabular}{lll}
\hline Items & Biorefinery & Ethanol plant \\
\hline Capital investment (million \$) & 388.75 & 197.40 \\
Variable operating costs (million \$/year) & 111.20 & 41.50 \\
Fixed operating costs (million \$/year) & 14.78 & 7.54 \\
NPV (million \$) & 1695.48 & 59.72 \\
IRR (\%) & 46 & 13 \\
\hline
\end{tabular}

Table 4

Results of sensitivity analysis on (a) capital investment (b) price of succinic acid (c) price of ethanol (d) price of stover.

\begin{tabular}{|c|c|c|c|}
\hline & Capital investment (million \$) & NPV (million \$) & $\operatorname{IRR}(\%)$ \\
\hline \multicolumn{4}{|l|}{ (a) } \\
\hline Present case & 388.75 & 1695.48 & 46 \\
\hline Scenarios I $(2 \times)$ & 777.50 & 1276.87 & 26 \\
\hline Scenarios II $(4 \times)$ & $1,555.00$ & 439.65 & 13 \\
\hline \multirow[t]{2}{*}{ Ethanol plant } & 197.40 & 59.72 & 13 \\
\hline & Price of succinic acid $(\$ / \mathrm{kg})$ & NPV (million \$) & $\operatorname{IRR}(\%)$ \\
\hline \multicolumn{4}{|l|}{ (b) } \\
\hline Present case & 1.0 & 1695.48 & 46 \\
\hline Scenarios I $(0.5 \times)$ & 0.5 & 474.00 & 23 \\
\hline Scenarios II $(2 \times)$ & 2.0 & 4138.43 & 79 \\
\hline \multirow[t]{2}{*}{ Ethanol plant } & - & 59.72 & 13 \\
\hline & Price of ethanol $(\$ / \mathrm{kg})$ & NPV (million \$) & $\operatorname{IRR}(\%)$ \\
\hline \multicolumn{4}{|l|}{ (c) } \\
\hline Present case & 0.357 & 1695.48 & 46 \\
\hline Scenarios I $(0.5 \times)$ & 0.179 & 1442.95 & 42 \\
\hline Scenarios II $(2 \times)$ & 0.714 & 2200.53 & 54 \\
\hline \multirow[t]{2}{*}{ Ethanol plant } & 0.357 & 59.72 & 13 \\
\hline & Price of corn stover $(\$ / \mathrm{kg})$ & NPV (million \$) & $\operatorname{IRR}(\%)$ \\
\hline \multicolumn{4}{|l|}{ (d) } \\
\hline Present case & 0.033 & 1695.48 & 46 \\
\hline Scenarios I $(1.5 \times)$ & 0.050 & 1514.66 & 43 \\
\hline Scenarios II $(2 \times)$ & 0.066 & 1333.85 & 40 \\
\hline Ethanol plant & 0.033 & 59.72 & 13 \\
\hline
\end{tabular}

because the usual IRR is reported as $20-30 \%$. However, when it becomes four times as high, the biorefinery does not show any advantage over the ethanol plant.

Increased market price of succinic acid brings more profit (IRR $79 \%$ ), and even when the price decreases to half a dollar, the IRR is $(23 \%)$ still much higher than the one of the ethanol plant. The fluctuations in ethanol price give less significant changes in NPV and IRR. In the future the price of the harvested stover is expected to increase; however, this increase does not affect the profit significantly due to the high value derived from the refinery, and affect the ethanol plant similarly.

\subsection{Environmental impact assessment}

The environmental performance of the biorefinery, ethanol plant and gasoline refinery per impact category is given in Table 5. These results cannot be directly compared due to the difference in products and plant capacity of the three systems. Nevertheless, they can act as basic information for the further estimation of the eco-efficiency of the biorefinery, as is done below in Section 3.3. Such an eco-efficiency analysis enables a comparison with other production systems as well.

\subsection{Comparison of eco-efficiency}

The comparative results of the three aforementioned systems are shown in Fig. 2. Internal normalization is performed by setting the results from gasoline refinery to 1 and the ones from biorefinery and ethanol plant can therefore be compared. As the eco-effi-
Table 5

Environmental performance of the three refineriesbiorefinery (b) ethanol plant (c) gasoline refinery.

\begin{tabular}{|c|c|c|}
\hline Impact category & Value & Unit $^{\mathrm{a}}$ \\
\hline \multicolumn{3}{|l|}{ (a) } \\
\hline ADP & $4,596,025$ & $\mathrm{~kg}$ antimony eq./year \\
\hline GWP & $-260,771,475$ & $\mathrm{~kg} \mathrm{CO} 2$ eq./year \\
\hline ODP & 46 & kg CFC-11 eq./year \\
\hline POCP & 386,974 & kg ethylene eq./year \\
\hline HTP & $165,470,547$ & kg 1,4-dichlorobenzene eq./year \\
\hline ETP & $231,594,742$ & kg 1,4-dichlorobenzene eq./year \\
\hline AP & $5,981,320$ & $\mathrm{~kg} \mathrm{SO}{ }_{2}$ eq./year \\
\hline $\mathrm{EP}$ & 987,018 & $\mathrm{~kg} \mathrm{PO}_{4}$ eq./year \\
\hline $\begin{array}{l}\text { Impact category } \\
\text { (b) }\end{array}$ & Value $^{\mathrm{b}}$ & Unit \\
\hline ADP & $3.25 \times 10^{-3}$ & $\mathrm{~kg}$ antimony eq./kg ethanol \\
\hline GWP & 2.18 & $\mathrm{~kg} \mathrm{CO}$ eq./kg ethanol \\
\hline ODP & $9.64 \times 10^{-8}$ & $\mathrm{~kg}$ CFC- 11 eq./kg ethanol \\
\hline POCP & $1.74 \times 10^{-3}$ & $\mathrm{~kg}$ ethylene eq./kg ethanol \\
\hline HTP & $1.13 \times 10^{-1}$ & kg 1,4-dichlorobenzene eq./kg ethanol \\
\hline ETP & $2.16 \times 10^{-1}$ & kg 1,4-dichlorobenzene eq./kg ethanol \\
\hline AP & $6.88 \times 10^{-3}$ & $\mathrm{~kg} \mathrm{SO} \mathrm{S}_{2}$ eq. $/ \mathrm{kg}$ ethanol \\
\hline EP & $1.28 \times 10^{-3}$ & $\mathrm{~kg} \mathrm{PO}_{4}$ eq./kg ethanol \\
\hline $\begin{array}{l}\text { Impact category } \\
\text { (c) }\end{array}$ & Value $^{c}$ & Unit \\
\hline ADP & $2.62 \times 10^{-2}$ & $\mathrm{~kg}$ antimony eq./gasoline \\
\hline GWP & $7.00 \times 10^{-1}$ & $\mathrm{~kg} \mathrm{CO} \mathrm{CO}_{2}$ eq./gasoline \\
\hline ODP & $4.72 \times 10^{-7}$ & kg CFC- 11 eq./gasoline \\
\hline POCP & $1.78 \times 10^{-3}$ & $\mathrm{~kg}$ ethylene eq./gasoline \\
\hline HTP & $1.89 \times 10^{-1}$ & $\mathrm{~kg}$ 1,4-dichlorobenzene eq./gasoline \\
\hline ETP & $4.13 \times 10^{-2}$ & kg 1,4-dichlorobenzene eq./gasoline \\
\hline $\mathrm{AP}$ & $8.05 \times 10^{-3}$ & $\mathrm{~kg} \mathrm{SO}{ }_{2}$ eq./gasoline \\
\hline EP & $6.65 \times 10^{-4}$ & $\mathrm{~kg} \mathrm{PO}_{4}$ eq./gasoline \\
\hline
\end{tabular}

a As multiple products are produced in the refinery, the "environmental impact per year" is used as unit.

b Data obtained from Luo et al. (2009).

c Data obtained from the Ecoinvent database: http://www.ecoinvent.org/.

ciency in this study is defined as 'emissions per dollar of output', lower eco-efficiency values represent better performance of the system.

The most striking result comes from GWP. In this category, the negative value for the biorefinery does not indicate a worse performance, but a substantially better one. In the biorefinery, a large fraction of the $\mathrm{CO}_{2}$ emitted by the ethanol fermentation process is fixed by acid fermentation. Moreover, the use phase of the different products is not included in the study. This leads to negative GHG emissions, as can already be seen in Table $5 .{ }^{1}$ This shows that the combined production of ethanol and succinic acid is indeed a more promising option. The reason why the eco-efficiency of the ethanol plant is significantly worse than that of the gasoline refinery is twofold: (1) the contribution of agriculture related emissions to the total, which is significant and does not occur in the gasoline refinery, ${ }^{2}$ and $(2)$ the market price of ethanol $(\$ 0.36 / \mathrm{kg})$ is much lower than gasoline $(\$ 0.98 / \mathrm{kg})$, which however includes some excises. The price before excises is substantially lower, depending on state and country. Therefore, more value per $\mathrm{kg}$ of GHG emissions is created by gasoline refining.

The eco-efficiencies of the biorefinery and the ethanol plant are better than the one of gasoline refinery in the category of ADP and ODP. This is obviously due to the replacement of fossil resources by

\footnotetext{
${ }^{1}$ In case the co-produced electricity is used on-site, the GHG emissions would be even more negative since less fossil electricity would have to be obtained from the grid. The difference would be in the order of magnitude of $100,000 \mathrm{~kg} \mathrm{CO}$-eq, or $0.05 \%$ of the total.

2 Due to application of economic value-based allocation between corn and stover in agriculture, a small part of agricultural emissions are allocated to the corn stover. The effect of different allocation methods has been extensively studied in one of our previous papers (Luo et al., 2009).
} 


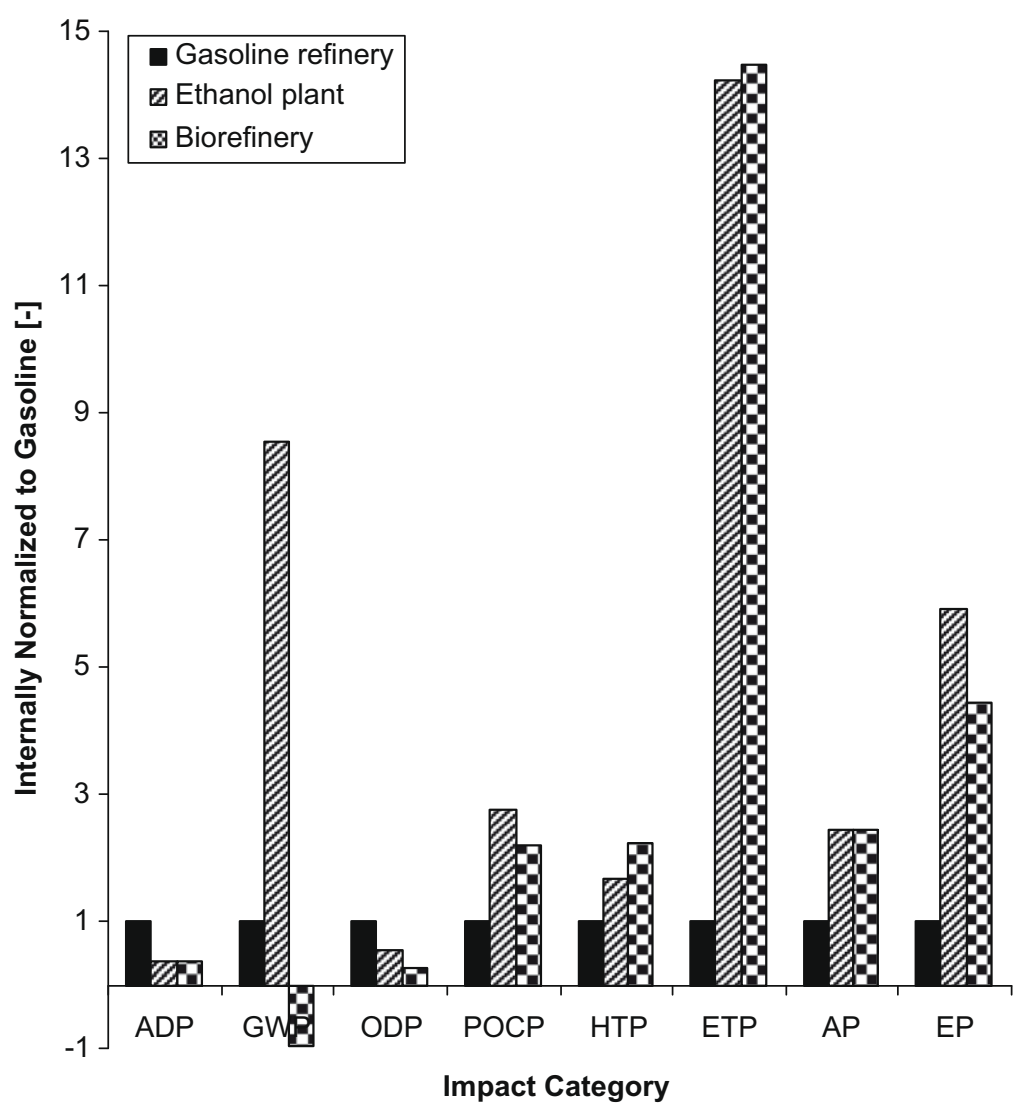

Fig. 2. Comparative results eco-efficiency for three production systems (lower values represent better results).

renewables - corn stover in this case. Crude oil, natural gas, and coal are the main contributors to abiotic depletion, while the ODP level is mainly contributed by the emissions from the crude oil production onshore.

In the rest of the impact categories, biorefining performs worse than gasoline refinery. In biorefinery and ethanol plant, although emissions causing POCP from natural gas production and oil exploitation decrease, the ones from ethanol production contribute even more to POCP level. Moreover, agriculture contributes largely to human and eco-toxicity, acidification, and eutrophication due to the use of agrochemicals; thus, gasoline is a better option in terms of these impacts.

In most of the impact categories the biorefinery has a better eco-efficiency than ethanol plant, which is attributed to the high value of the succinic acid derived from such a refinery. In terms of human toxicity the result is opposite - the ethanol plant has slightly better eco-efficiency. The emissions of heavy metals to air and water from agriculture are the major contributor to human toxicity. As for both production systems corn stover is used as feedstock, the resulting difference might be due to the different emissions from the refining process.

The biorefinery designed in this study has clear advantages over the ethanol plant in terms of eco-efficiency. However, when comparing biorefining to gasoline refinery, the overall evaluation of the eco-efficiency depends on the importance attached to each impact category.

\section{Discussion}

In the present study the productions of low-value product ethanol and high-value product succinic acid are combined to maximize the values derived from biomass refining. Acetic acid is co-produced from succinic acid fermentation; hence it is also harvested as a co-product. Steam and electricity are generated from lignin residues and refinery wastes. Corn stover is selected as a lignocellulosic feedstock due to its high availability for non-food uses. From the feedstock handling and pre-treatment till product purification, the refinery has been conceptually designed to provide technical process data for the environmental and economic analysis.

The systems analysis applied in this paper aims at estimating the net present value, internal rate of return and eco-efficiency of the biorefinery, compared to ethanol production and gasoline production. The economic model is based on discounted cash flow, which reflects a usual business approach. Sensitivity analyses provide indications on how profitable biorefining is.

No straightforward conclusion can be drawn with regard to the eco-efficiency analysis relative to gasoline. However, the GHG benefits of the biorefinery are remarkable compared to both the gasoline refinery and the ethanol plant. The eco-efficiencies of biorefinery and ethanol plant are better than the one of gasoline refinery in the category of ADP and ODP. For the rest of the impact categories, the gasoline refinery has the best performance. For all the impact categories except human toxicity and eutrophication, the biorefinery has a better eco-efficiency than the ethanol plant, which is attributed mainly to the high values derived from such a refinery. The overall evaluation of the eco-efficiency thus depends on the importance attached to each impact category. A more substantial environmental analysis is needed to identify the hotpots in the chains, and therefore to suggest improvement options.

The price of gasoline used in this study includes excises; while for ethanol not excises but subsidies have been exerted. Therefore the outcomes are based on these assumptions. In the future if excises are exerted also on ethanol, the results of comparison will be much different. 
From idea to operation of any new production is always time consuming due to a series of actions - innovation and research, technology transfer, business investment, conceptual process design, test in pilot scale, upscale and establishment of an operational plant. All these activities make the realization of such a biorefinery difficult but not impossible; ten years can be a good estimate to bring the products from our refinery into market.

The LCF biorefinery has been designed and optimized; process technologies and system analysis have been linked. However, due to the time limitation and scope of the study, some relevant issues have not been addressed, as follows:

- Corn stover is just one type of lignocellulosic feedstocks, but is produced with very high regional yields. The regional dependency of the feedstocks is of crucial importance, also outside the US. Large amounts of the cellulosic biomass will have to be grown locally or cheap transport must be available, especially bulk water transport.

- The choice of the product combination is of crucial importance for biorefinery design. In this case ethanol and succinic acid are produced in the refinery together for one important environmental reason $-\mathrm{CO}_{2}$ released by ethanol fermentation can be fixed by acid fermentation, which causes very substantial GHG benefits. This should be an additional criterion in the list of product selection criteria mentioned in Section 2.1.

- The ratio of ethanol/succinic acid production selected in this study is only one choice. When the market changes, the shift from one product to the other is possible to full extent - one product line can be shut down completely or ready for the production of other fuels or chemicals, for instance, succinic acid can be replaced by the production of other dicarboxylic acids which can then be used in industrial polymerization processes. On the other hand, if 1,4-butanediol, polysuccinate esters or polyamides is produced from succinic acid in the refinery, more installations can be also added to serve the purpose. Moreover, acetic acid is one of the important bulk chemicals with already established market and reasonably high price $(0.7 \$ / \mathrm{kg})$ compared to ethanol, production of more acetic acid can always be profitable.

- The system analysis of the designed biorefinery firstly provides the absolute environmental and economic performance. Due to the difficulties in comparing these absolute values, an ecoefficiency indicator has been defined. The estimation and comparison of eco-efficiency give an indication on the relative performance of different production systems. In this type of study, in order to achieve better eco-efficiency one can increase profit of a refinery instead of reducing emissions to environment. This provokes the discussion on "strong sustainability" and "weak sustainability", a concept introduced by Daly (1990) and Dietz and Neumayer (2007), and is also recognized in the eco-efficiency field - see for example by Huppes and Ishikawa (2009). Methodology development for systems analysis of biorefining is still of crucial importance.

- Last but not least, two software packages are used separately SuperPro Designer for technical process simulation and CMLCA for environmental assessment. The connection of these tools was made manually. In future studies, software development can help establish a linkage between process simulation and environmental assessment so that optimizations can be done in a more integrated way.

\section{Conclusions}

System analysis shows that the designed biorefinery has great potential in terms of profit compared to ethanol plant. Even when the price of the high-value succinic acid is lowered or the capital investment is doubled, the refinery is still highly profitable. Fluctuations in the price of ethanol and corn stover affect the profitability of the refinery less significantly. Eco-efficiency analysis shows a great reduction of greenhouse gas emissions due to the $\mathrm{CO}_{2}$ fixation by acid fermentation, which indicates the combined production of ethanol and succinic acid is indeed beneficial in a relative term (value created per unit of emissions).

\section{Acknowledgement}

This project is financially supported by the Netherlands Ministry of Economic Affairs and the B-Basic partner organizations (www. b-basic.nl) through B-Basic, a public-private NWO-ACTS program (ACTS $=$ Advanced Chemical Technologies for Sustainability).

\section{References}

Aden, A., Ruth, M., Ibsen, K., Jechura, J., Neeves, K., Sheenhan, J., et al., 2002 Lignocellulosic Biomass to Ethanol Process Design and Economics Utilizing Cocurrent Dilute Acid Prehydrolysis and Enzymatic Hydrolysis for Corn Stover. NREL/TP-510-32438, NREL.

Baum, P., Engelmann, J., 2001. Applied macromolecular chemistry. Nachr Chemie 49, 368-373.

Bechthold, I., Bretz, K., Kabasci, S., Kopitzky, R., Springer, A., 2008. Succinic acid: a new platform chemical for biobased polymers from renewable resources. Chem. Eng. Technol. 31 (5), 647-654.

BIOPRO: <http://www.biopro.eu/magazin/wirtschaft/index.html?lang=en\&artikelid= /artikel/03558/index.html> (assessed May 2009).

Chain Management by Life Cycle Assessment: <http://cml.leiden.edu/software/> (assessed January 2009).

Daly, H.E., 1990. Sustainable Development: From Concept and Theory to Operational Principles. Population and Development Review. Supplement: Resources, Environment and Population: Present Knowledge, Future Options, vol. 16. pp. 25-43.

Dietz, S., Neumayer, E., 2007. Weak and strong sustainability in the SEEA: concepts and measurement. Ecol. Econ. 61 (4), 617-626.

Efe, C., Straathof, A.J.J., van der Wielen, L.A.M., 2005. Technical and economical feasibility of production of ethanol from sugarcane and sugarcane Bagasse. In: B-Basic Internal Report. ISBN: 978-90-809691-6-2.

Energy Information Administration: <http://www.eia.doe.gov/> (assessed June 2009).

Graham, R.L., Nelson, R., Sheehan, J., Perlack, R.D., Wright, L.L., 2007. Current and potential US corn stover supplies. Agron. J. 99, 1-11.

Huppes, G., Ishikawa, M., 2009. Eco-efficiency guiding micro-level actions towards sustainability: ten basic steps for analysis. Ecol. Econ. 68, 1687-1700.

ISIC Pricing: <http://www.icispricing.com/il_shared/Samples/SubPage167.asp> (assessed May 2009).

Kadam, K.L., Chin, C.Y., Brown, L.W., 2008. Flexible biorefinery for producing fermentation sugars, lignin and pulp from corn stover. J. Ind. Microbiol. Biotechnol. 35, 331-341.

Kamm, B., Kamm, M., 2004. Principles of biorefinery. Appl. Microbiol. Biotechnol. 64, 137-145.

Kaparaju, P., Serrano, M., Thomsen, A.B., Kongjan, P., Angelidaki, I., 2009. Bioethanol, biohydrogen and biogas production from wheat straw in a biorefinery concept. Bioresour. Technol. 100, 2562-2568.

Landucci, R., Goodman, B., Wyman, C., 1994. Methodology for evaluating the economics of biologically producing chemicals and materials from alternative feedstocks. Appl. Biochem. Biotechnol. 45 (46), 677-696.

Laser, M., Jin, H., Jayawardhana, K., Dale, B.E., Lynd, L.R., 2009a. Projected mature technology scenarios for conversion of cellulosic biomass to ethanol with coproduction thermo-chemical fuels, power, and/or animal feed protein. Biofuels Bioprod. Bioref. 3, 231-246.

Laser, M., Larson, E., Dale, B.E., Wang, M., Greene, N., Lynd, L.E., 2009b. Comparative analysis of efficiency, environmental impact, and process economics for mature biomass refining scenarios. Biofuels Bioprod. Bioref. 3, 247-270.

Luo, L., van der Voet, E., Huppes, G., 2009. Allocation issues in LCA methodology: a case study of corn stover-based fuel ethanol. Int. J. Life Cycle Assess. 14, 529539.

Lynd, L.R., Wyman, C., Laser, M., Johnson, D., Landucci, R., 2005. Strategic Biorefinery Analysis: Analysis of Biorefineries. NREL/SR-510-35578, NREL.

McAloon, A., Taylor, F., Yee, W., Ibsen, K., Wooley, R., 2000. Determining the Cost of Producing Ethanol from Corn Starch and Lignocellulosic Feedstocks. NREL/TP580-28893, NREL.

McKinlay, J.B., Vieille, C., Zeikus, J.G., 2007. Prospects for a bio-based succinate industry. Appl. Microbiol. Biotechnol. 76, 727-740.

Nghiem, N.P., Davison, B.H., Suttle, B.E., Richardson, G.R., 1997. Production of succinic acid by Anaerobiospirillum succiniciproducens. Appl. Biochem. Biotechnol. 63-65, 565-576.

NREL Biomass Research: <http://www.nrel.gov/biomass/biorefinery.html> (assessed June 2009). 
Okino, S., Noburyu, R., Suda, M., Jojima, T., Inui, M., Yukawa, H., 2008. An efficient succinic acid production process in a metabolically engineered Corynebacterium glutamicum strain. Appl. Microbiol. Biotechnol. 81, 459-464.

Paster, M., Pellegrino, J.L., Carole, T.M., 2003. Industrial Bio-products: Today and Tomorrow. Energetics, Incorporated, Columbia, MD.

Realff, M.J., Abbas, C., 2004. Industrial symbiosis - refining the biorefinery. J. Ind. Ecol. 7 (3-4), 5-9.

Rudner, M.S., Jeremic, S., Petterson, K.A., Kent, D.R., Brown, K.A., Drake, M.D., et al., 2005. Intramolecular hydrogen bonding in disubstituted ethanes. A comparison of $\mathrm{NH} \cdots \mathrm{O}-$ and $\mathrm{OH} \cdots \mathrm{O}$ - hydrogen bonding through conformational analysis of 4-amino-4-oxobutanoate (succinamate) and monohydrogen 1,4-butanoate (monohydrogen succinate) anions. J. Phys. Chem. A 109, 9076-9082.

Samuelov, N.S., Lamed, R., Lowe, S., Zeikus, J.G., 1991. Influence of $\mathrm{CO}_{2}-\mathrm{HCO}_{3}{ }^{-}$levels and $\mathrm{pH}$ on growth, succinate production, and enzyme activities of Anaerobiospirillum succinicproducens. Appl. Environ. Microbiol. 57, 3013-3019.

Saving Electricity: <http://michaelbluejay.com/electricity/cost.html> (assessed May 2009).

Schmidheiny, S., 1992. Changing Course: A Global Business Perspective on Development and the Environment. ISBN: 0-262-69153-1.

Sheehan, J., Aden, A., Riley, C., Paustian, K., Brenner, J., Lightle, D., et al., 2002. Is ethanol from corn stover sustainable? Adventures in Cyber-farming: A Life Cycle Assessment of the Production of Ethanol from Corn Stover for Use in a Flex Fuel Vehicle. Draft Report for Peer Review, Colorado, NREL.

Short, W., Packey, D.J., Holt, T., 1995. A Manual for Economic Evaluation and Energy Efficiency and Renewable Energy Technologies. NREL/TP-462-5173, NREL, Golden, CO.
Song, H., Lee, S.Y., 2006. Production of succinic acid by bacterial fermentation. Enzyme Microb. Technol. 29, 352-361.

Sun, Y., Cheng, J., 2002. Hydrolysis of lignocellulosic materials for ethanol production: a review. Biosour. Technol. 83, 1-11.

Swiss Centre of Life Cycle Inventories. Ecoinvent database. Available online: <http:// www.ecoinvent.org/> (assessed May 2009).

van Dyne, D.L., Blase, M.G., Clements, L.D., 1999. A strategy for returning agriculture and rural America to long-term full employment using biomass refineries. In: Janick, J. (Ed.), Perspectives on New Crops and New Uses. ASHS Press, Alexandria, VA.

Willke, Th., Vorlop, K.-D., 2004. Industrial bioconversion of renewable resources as an alternative to conventional chemistry. Appl. Microbiol. Biotechnol. 66, 131142.

Wood, W.A., 1961. Fermentation of carbohydrates and related compounds. In: Gunsalus, I.C., Stanier, R.Y. (Eds.), The Bacteria, vol. 2. Academic Press, pp. 59149.

Zeikus, J.G., 1995. Chemical and fuel production by anaerobic bacteria. Annu. Rev. Microbiol. 34, 423-464.

Zeikus, J.G., Jain, M.K., Elankovan, P., 1999. Biotechnology of succinic acid production and markets for derived industrial products. Appl. Microbiol Biotechnol. 51, 545-552.

Zhang, M., Eddy, C., Deanda, K., Finkelstein, M., Picataggio, S., 1995. Metabolic engineering of a pentose metabolism pathway in Zymomonas mobilis. Science 267, 240-243. 